\title{
A STUDY OF ARCHITECTURE IN GUJARAT FROM PAST TO PRESENT
}

\section{Dr. Priyanki Vyas \\ Ms. Daxa G. Patel}

\begin{abstract}
:
This research aims to focus upon the architecture of Gujarat from past till present times, here the researcher will give the combined information regarding traditional architectural forms of constructing the buildings, palaces, markets, schools and other important places where local people lived in ancient era. The phases of development from past to present times, in which creativity, imagination and culture mattered equally as climate and materials used. Different monuments such as Rani Ki Vav, Sun temple, Jhulta Minarets, Sidi Saiyyed mosque and others are discussed from past, while Sabarmati Riverfront, Statue of Unity, modern materials and homes are elaborated by the researcher. In the $20^{\text {th }}$ century the classical architecture was replaced by modern and contemporary architecture. One while talking about the modern architecture of Ahmedabad the capital of Gujarat can never do without mentioning the works of Ar. B.V. Doshi the father of modern architecture.
\end{abstract}

Key-words: Ahmedabad, Ancient Architecture, Architecture, Gujarat, Lothal, Modern Architecture, Monuments.

\section{Introduction:}

Gujarat has excellent infrastructure as compared to other states. Gujarat is located on the Western coast of India and consist longest coastline, sharing its border with Rajasthan, Madhya Pradesh, Maharashtra and also the Union Territories of Daman and Diu and Dadra and Nagar Haveli. On West and South-west States are borders of Arabian Sea.203 Monuments of National Importance have been recognized by the ASI in Gujarat. Royal Palaces, Havelis, Poles, Forts, Step-wells, Spiritual Architecture, Colonial Structure, Historical Sites are included in this vast architectural history of Gujarat. "Gurjaradesa" is a Sanskrit term from which the word Gujarat is 
obtained, it means as "The Land of Gujaras". Gujjaras who ruled in Gujarat from $8^{\text {th }}$ to $9^{\text {th }}$ centuries have been known as "Gujaratra" or "Gujarabhumi" from old Mughal period. Gujarat is a state in the western part in India known locally as jewel of the western part of India. Its capital is Gandhinagar. Architecture refers as three-dimensional work as it includes designing, construction and also sculpting. Architecture involves study of engineering and mathematics depending upon the measurements and perfect used of material, whereas sculpting binds up with creativity and imagination. From past till present architecture of Gujarat, followed the major styles of construction through this fundamental only.

\section{Traditional forms of Architecture in the Past:}

Gujarat has the most indigenous Indian style of all other provincial styles. Mainly due to its powerful Ahmed Shahi dynasty who surrounded themselves with its architectural evidences and also due to the skilful workers who made the masterpiece every time with the use of their might. In the past The Bhonga style of construction was the most traditional style of Kutch in Gujarat. This style of construction was used in Kutch district as they had risk of earthquake, Bhonga has a conical roof supported by cylindrical walls. Many other historical monuments also consist of same shape and style because of its mindful architecture. Indo-Islamic architecture prospered during the rule of Mughal Empire. Gujarat is a beautiful land filled with several historical and Heritage places, which unfolds its mystic experience with diverse culture. Some of the famous Architectural pieces are Rani Ki Vav, Sidi Sayed Mosque, Adalaj Step-well, Bai Harir Vav, Pavagadh fort, Sun Temple Modhera, Jami Masjid, Jhulta Minaret, Laxmi Vilas Palace, Palitana Temples, Bhadra Fort, Dwarkadish Temple, Hatheesing Jain Temple etc. Lothal and Dholavira are the most ancient civilization, other than that Indus Valley Civilization is the main platform to form the base of Gujarat and its Gothic style of architecture. In the earlier history of Gujarat there was imperial grandeur of Chadragupta Maurya who won a number of states are now a part of Gujarat. It was one of the main central areas of the Indus valley civilization, it contains ancient cities from Lothal, Dholavira and Gola Dhoro. Where in Lothal India first Port was established. The ancient city of Dholavira is one the largest and most prominent sites in India.

\section{Different phases of Architecture in Past:}

The ancient history of Gujarat was flourished by the trade activities of its inhabitants, from Egypt and Bahrain mostly and also adapted their style of construction in that era. Since $14^{\text {th }}$ century A.D there has been three periods of different architectural forms in Gujarat. The first phase 
from 1300-1458 was the period which consisted of the customary phase of demolition of temples followed by reconversion of the building materials. The buildings of this period are more of experimental and formative. The second phase was first half of $15^{\text {th }}$ century A.D this was Ahmed Shahi period where the buildings and monuments were designed in authorisation of the emperor. The third phase was second half of $15^{\text {th }}$ century with more magnificent aspect of style the inner beauty of the monument was more artful and filled with different aspects of lives of the people of Gujarat. The use of marble and mirror was most prominent as followed from Mughal art. The traditional forms were symbol of great prosperity of India.

The main component of a traditional architecture style is the way in which the past buildings and present are merged together keeping in mind the importance of its functions and work due to which there is smooth transition of tradition and culture from past to present, the versatility is of craftsmanship also plays an important role in this, taking into consideration the climate and objective of the particular building.

\section{Famous Architectural pieces of Gujarat: -}

1. Rani ki Vav (Queen's stepwell): It is located on the banks of river Saraswati. It was constructed as an attribute to queen Udayamati, queen of Solanki dynasty of $11^{\text {th }}$ century. It is a finest example of design as an inverted temple highlighting the sanctity of water, the stepwell is divided in to seven level of stairs with sculptural panels, more than five hundred major sculptures and over a thousand minor ones combine religious, Mythological and Secular imagery. It was constructed during the rule of the Chalukya dynasty; thus the stepwell was reflecting the Maru-Gurjara architecture style, was built as the height of craftsmen's ability in stepwell construction also showcasing the mastery of complex technique and beauty and detail and proportion. There are two hundred and twelve pillars in the stepwell and the entrance is the located in the east while the well is located at the westernmost end, which is 10 meter in diameter and 30 meter deep which makes deep circular well.

2. Jhulta Minaras (Shaking Minarets): Also known as Sidi Basheer mosque, Jhulta Minaras constructed by a slave of Mahmood Bagda in year 1452. The Minaras are the tallest in Ahmedabad are now located to the north of Ahmedabad railway junction, made up of three stories told with carved balconies. A gentle shaking of either Minaras results in the other Minaras vibrating after a few second, though the connecting passage between them remains free of vibration, the phenomenon of this is still unknown till date. On the 
Towards Excellence: An Indexed, Refereed \& Peer Reviewed Journal of Higher Education / Dr. Priyanki

Vyas \& Ms. Daxa Patel / Page 386-398

Minaras the little details are filled using the stone carving method. Many other Minaras were also constructed after this masterpiece.

3. Sidi Saiyyed Mosque: Located in the heart of the city Lal Darwaja, Sidi Saiyyed jail was constructed in 1572 A.D one of the most famous mosque of Ahmedabad. It was entirely craved from a huge stone; the windows are latticework called as "Jalis". The rear wall was filled with square stone pierced panels in geometrical designs. The two windows at the central aisle have reticulated stones slabs carved in designs of intertwined trees and foliage and a palm motif. The central window arch of the mosque, where one would expect to see another intricate jail, is instead walled with stone. One of the best pieces of ancient architecture this mosque has very detailed cravings on the stone which makes it precious and highly commendable.

4. Lothal (Ruins): Situated at the southernmost cities of the Indus Valley Civilization Lothal is 4500-year-old city. It was the world's earliest dock, which connected the city to an ancient course of the Sabarmati River on the trade route between Harappan cities in Sindh and the peninsula of Saurashtra when the surrounding Kutch desert was a part of the Arabian Sea. The trade of Jewels, Ornaments, Gems and beads was held through this route, Lothal contributes one of the three measurements scales that are integrated and linear an ivory scale from Lothal has the smallest known decimal division in Indus civilization. The durability and accuracy of stone weights by blunting edges before publishing was ensured by the craftsman. It has deep underground drainage system and silting chambers for solid waste. Archaeologist have discovered gold pendants, charred ashes of terra-cotta cakes and pottery, bovine remains, beads and also other signs. Animal worship is also a sign of Harrapan civilization and its diversity of religion.

5. Sun Temple: Also recognised as Surya Mandir, Sun temple has its own interesting facts and major theories behind its construction. Built by King Bhima I, Sun temple is dedicated to the solar deity Surya. Its impressive Kalinga architecture that consists of $100 \mathrm{ft}$ high chariot being pulled by horses and wheels carved out of a single stone. The three outermost projections of, wall Gudhamandpa on each window followed till the doorway cut out of a huge stone. The roof of passage has stones slabs craved with rosettes. The doorway has craved figures of seated Surya in panels surrounded by dancers and amorous couples. The tall and short pillars are craved with shaft in square shape which starts with high roof and base is in octagonal shape. Covered with floral design makes it more natural and scenic. 
Towards Excellence: An Indexed, Refereed \& Peer Reviewed Journal of Higher Education / Dr. Priyanki

Vyas \& Ms. Daxa Patel / Page 386-398

The four metro cities of Gujarat other than Ahmedabad -Surat, Rajkot and Baroda also have some unusual masterpieces such as Surat castle, Surat clock tower, British Cemetery Surat, Dutch Garden, Andrews Library, Jubilee Garden in Rajkot, Lang library of Rajkot, Khambhadia Buddhist Caves, Ranjit Palace, Laxmi Vilas Palace in Vadodara, Ajwa-nimeta Dam and Gardens, Nazarbaug Palace, Kirti Stambh, Sayaji Baug, Champaner-Pavgadh, are some examples of architectural construction of past.

The Diu-jail, in union territory of west of India which is separated by Arabian Sea also has another union territory Daman, both shares beaches that are sun-kissed. Also, there are some churches which are an architectural star, Diu fort is famous around travellers that was constructed between 1535-1541, it is surrounded by the Arabian Sea on all three sides and by a canal on the last, making it almost impregnable. One can see leftover canons at the fort, from a time when they were functional. It also has a light-house.

At last summing up with this great architectural monument from past, one can know that all the traditional forms of building are followed considering the needs of people and culture that they followed, also the climate and spiritual emotions played a major role in constructing in that era. Even after independence in 1947 the British Neoclassical period; Indo-Saracenic architectural style was considered as provincial style. Including homes, schools, markets and many other common places these styles was carried forward. Also, in modern era these traditional styles of architecture is considered as most important because of its practical uses.

\section{Evolution of style and architecture in present times:}

With the end of ancient era the modern architecture became advance with ample of materials, machinery, workmen, advance in study and technique. A change was marked in the field of architecture when a French architect entered ATMA association and changed the location totally from the entrance to the end of their mills, this continued as the architect made major changes in the way of construction was done in that time. Modern bungalows were constructed with mixed Gothic style, due to which they looked like a palace. With use of more super built up area the plot is covered totally without wasting any space. Installation of huge artificial gardens, fountains, play area for adults and children was seen more in early 1964 period. Construction of theatres and cinemas was huge makeover of spectrum area.

The taste of people changed as they started travelling over the world and became more familiar with modern style of living in open space, constructing huge buildings with more storeys. 
Other than schools and hospitals also offices were constructed with more technique, the two significant and succeeding phases have been the rule of Solanki dynasty and Mughal era which formed the reign in Ahmedabad as Gujarat's capital. Among the contemporary architectures, our attention is drawn to Gajjar hall in Ahmedabad Law garden, Mahatma Gandhi Labour Institute and Balkrishna Doshi's office. Such are examples of mixed modern and contemporary style of architecture in Ahmedabad. Also, Amdavad ni Gufa has now turned into a youth café which was a creation of famous painter M. F. Hussain and collaboration of Balkrishna Doshi, it is an underground ferrocement structure with optimally structured roof shells in china mosaic protruding over ground. The famous hotel Patang at Ellis bridge Ahmedabad is also an architectural wonder which is a $200 \mathrm{ft}$ high Sky scrapper, revolving hotel is a phenomenal and milestone building of Ahmedabad. Architect Hasmukh Patel had designed this brilliant structure with High court of Gujarat, St. Xavier's Loyola high school and Dena bank at Ashram road.

Ahmedabad has been a home as well as playground for some of the most amazing architects in the history of India, apart from the historical buildings the modern architecture also flourished in Ahmedabad. The legendary names like Le Corbusier, Louis Khan, Charles Correa have signature buildings in Ahmedabad. The name of Architect B.V. Doshi is very famous for dotting modern construction. Sabarmati Riverfront is a waterfront being developed along the banks of River Sabarmati in Ahmedabad. Constructed in 2005 the major objective of project was environment improvement, social infrastructure and sustainable development. The average width of the river channel was 382 metres and the narrowest cross-section 330metres. It is uniformly narrowed to 263 metres without affecting its flood carrying capacity and the riverside land is reclaimed on both east and west to construct riverfront. It has parks and garden along with some café and restaurants on each side. Created by architect Bimal Patel riverfront is a famous example of modern architecture in Ahmedabad.

One of the finest examples of latest architecture is Statue of Unity of Sardar Vallabhbhai Patel, it is located in Kevadiya of Gujarat. Which is tallest statue with a height of 182 metres that is 597 feet, located at Narmada River, facing Sardar Sarovar Dam. The statute has Sardar's dhoticlad legs and the use of sandals for footwear rendered the design thinner at the base than at the top thereby affecting the stability. The statue was built to withstand winds of up to $180 \mathrm{kms}$ per hour and earthquakes measuring 6.5 on scale, that is aided by the use of two 250 tonnes tuned mass dampers ensuring maximum stability. 
Modern architecture emphasis on rectangular forms a horizontal and vertical lines, Morden homes tend to be on generous sites, and thus many, but not old, have to have meandering one story plans, stills column are used been exposed application, concrete block is used as a finishing material, concrete floors are stained and exposed, long-sprain still trusses permit open column free space, and radiant hitting system enhance human comfort. Material such as wood, brick, and stone are used in simplified ways reflecting a Morden architecture. Use of large expanses of glass in effect brings the building site in to the dramatic view. The best Morden home are provided which solar hitting in winter, living spaces are no longer defined by walls, doors and hallways. Living, dining and kitchen spaces tend to flow together as a part of one contiguous interior space. New and innovative technologies construction is the new idea other than glass, brick, plastic, bamboo, carbon fibre, photovoltaic sales and organic material are also in trend.

Modern architecture is considered progressive rather than regressive. Modern architecture expresses volume, balance and elimination of ornaments, modern styles and concepts, by contrast, took more quickly in commercial, industrial and residential architecture. Ranging from Italian Renaissance, Gothic, and baroque through the neo-classical age, modern architecture is more all about sustainable construction.

Here are some modern photos of architecture ranging from past till present:

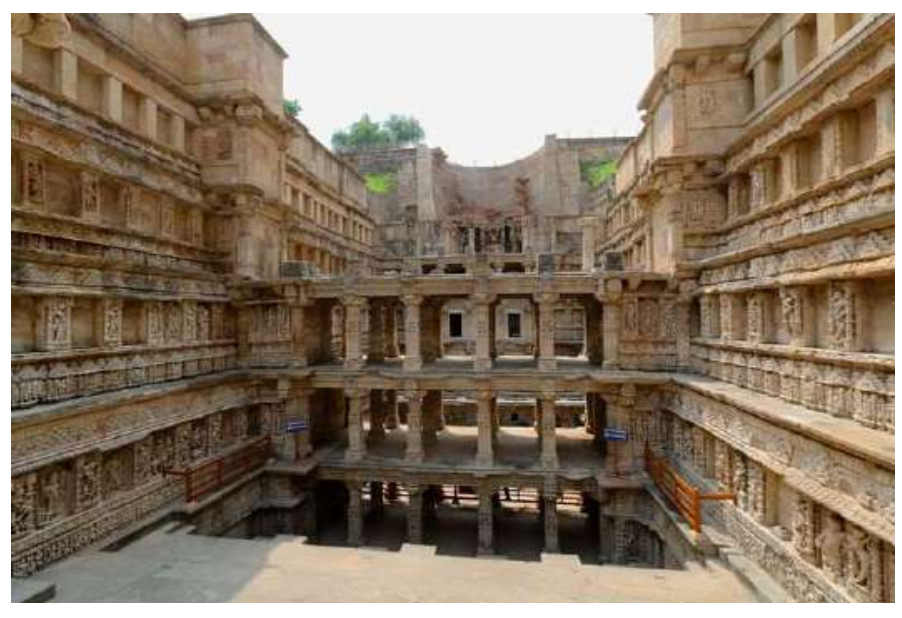

Rani ki Vav 
Towards Excellence: An Indexed, Refereed \& Peer Reviewed Journal of Higher Education / Dr. Priyanki Vyas \& Ms. Daxa Patel / Page 386-398
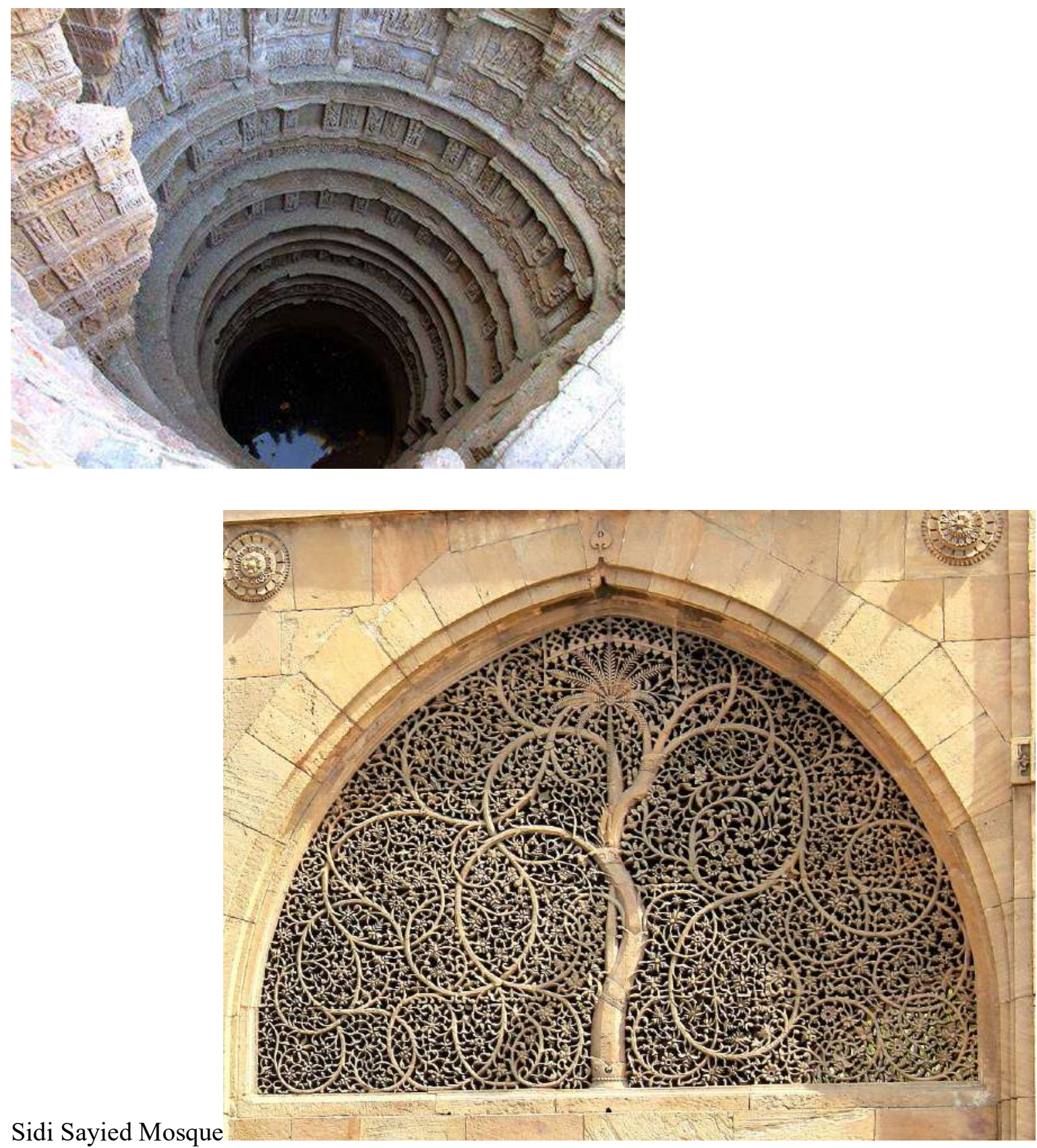

Modhera Sun Temple 
Towards Excellence: An Indexed, Refereed \& Peer Reviewed Journal of Higher Education / Dr. Priyanki Vyas \& Ms. Daxa Patel / Page 386-398

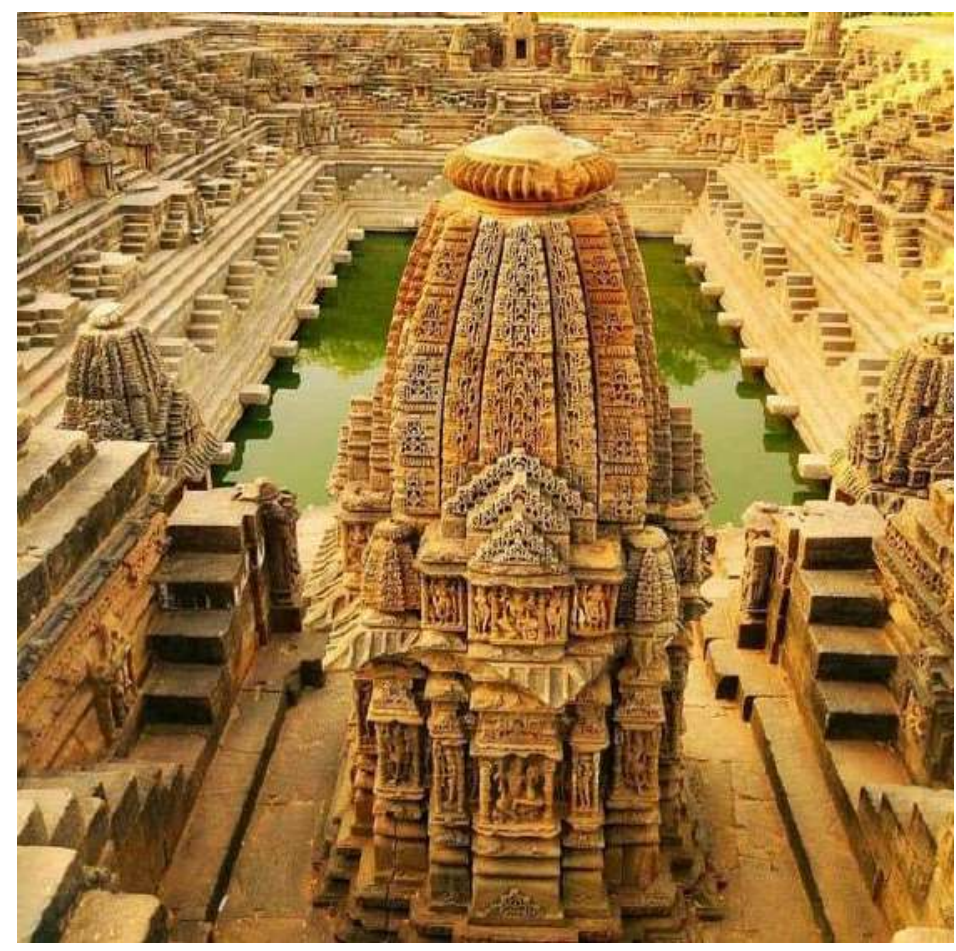

Sabarmati Riverfront:

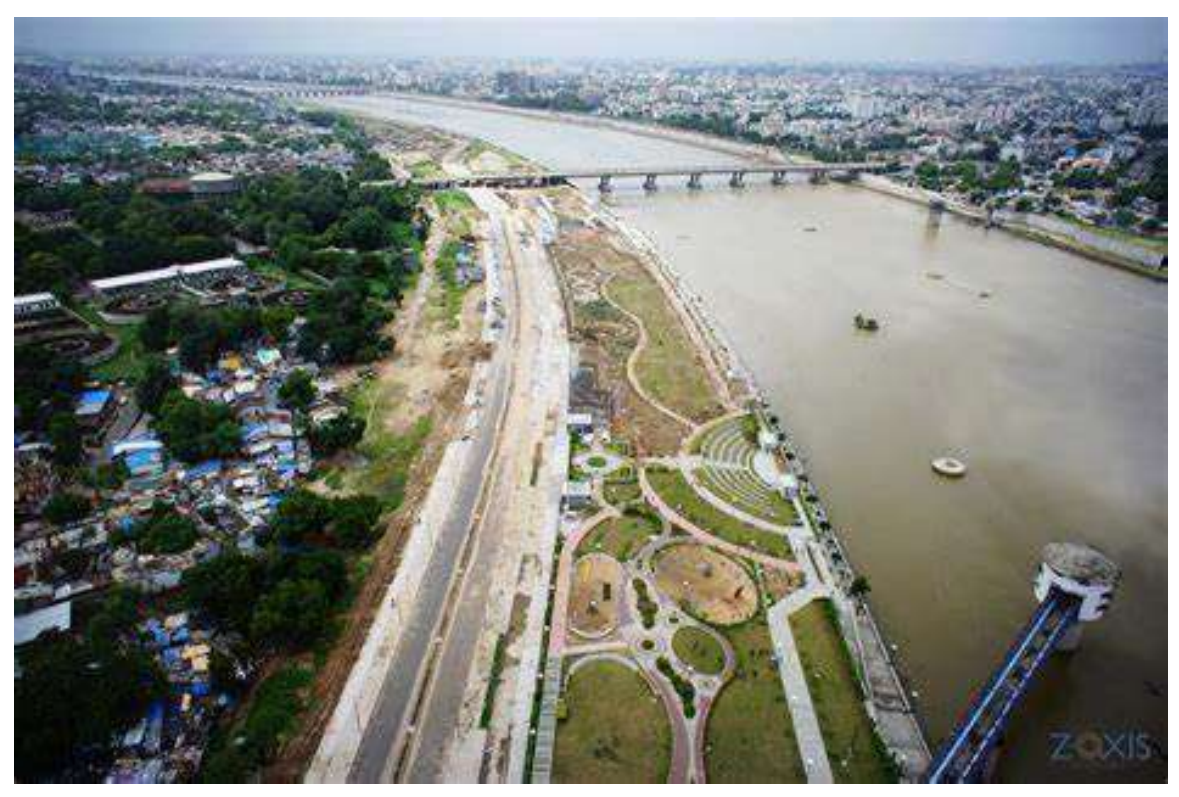

Statue of Unity: 
Towards Excellence: An Indexed, Refereed \& Peer Reviewed Journal of Higher Education / Dr. Priyanki Vyas \& Ms. Daxa Patel / Page 386-398

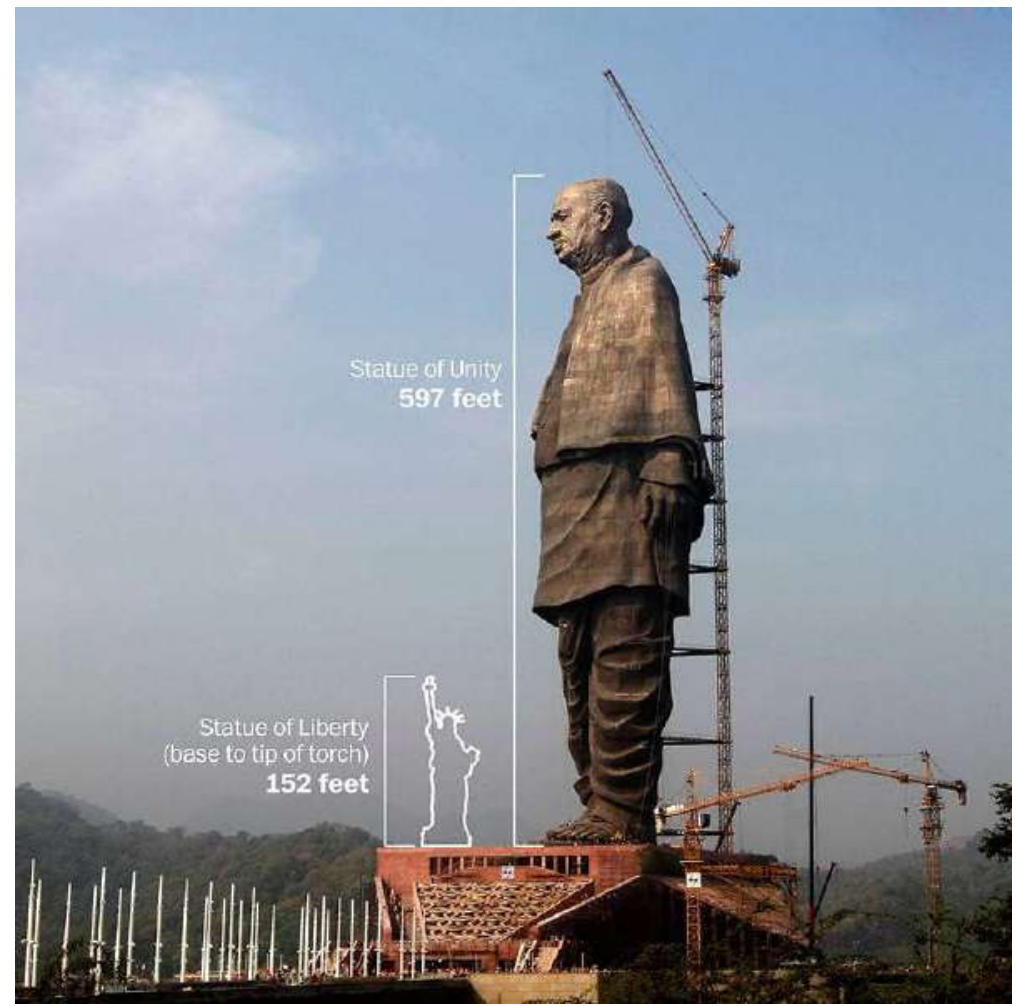

ATMA Association Mills:

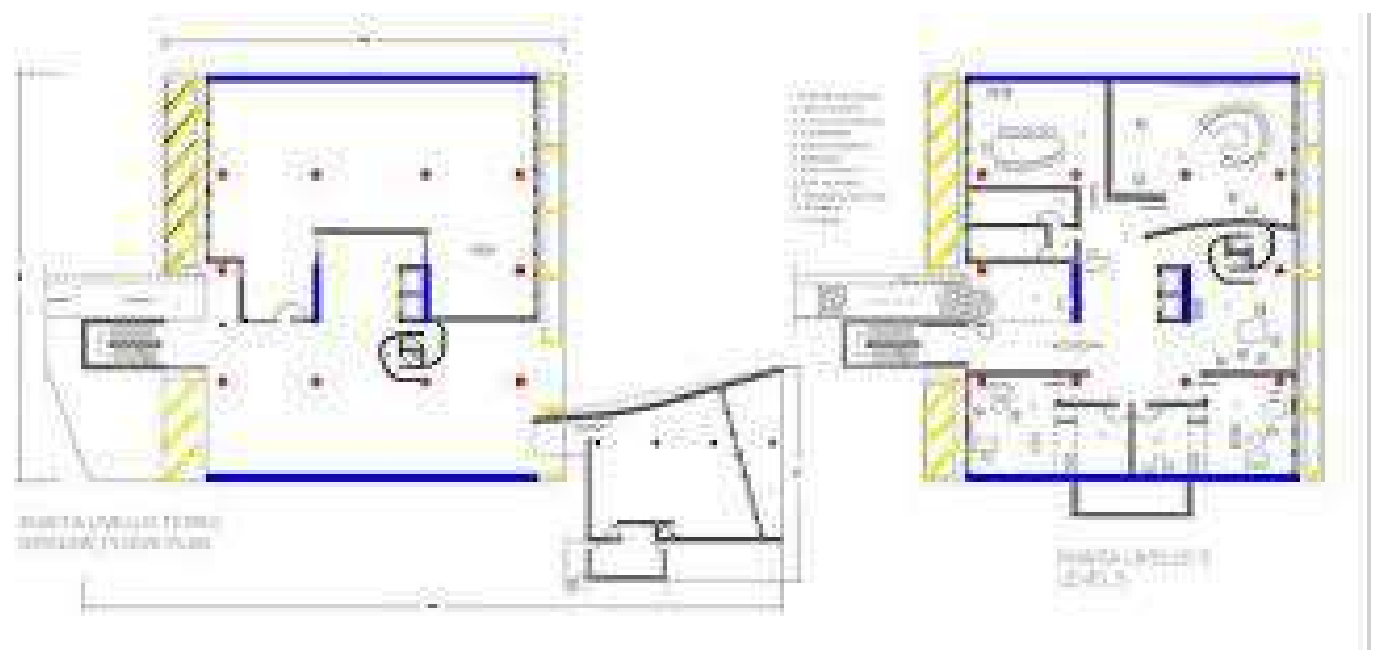


Laxmi Villas Palace:

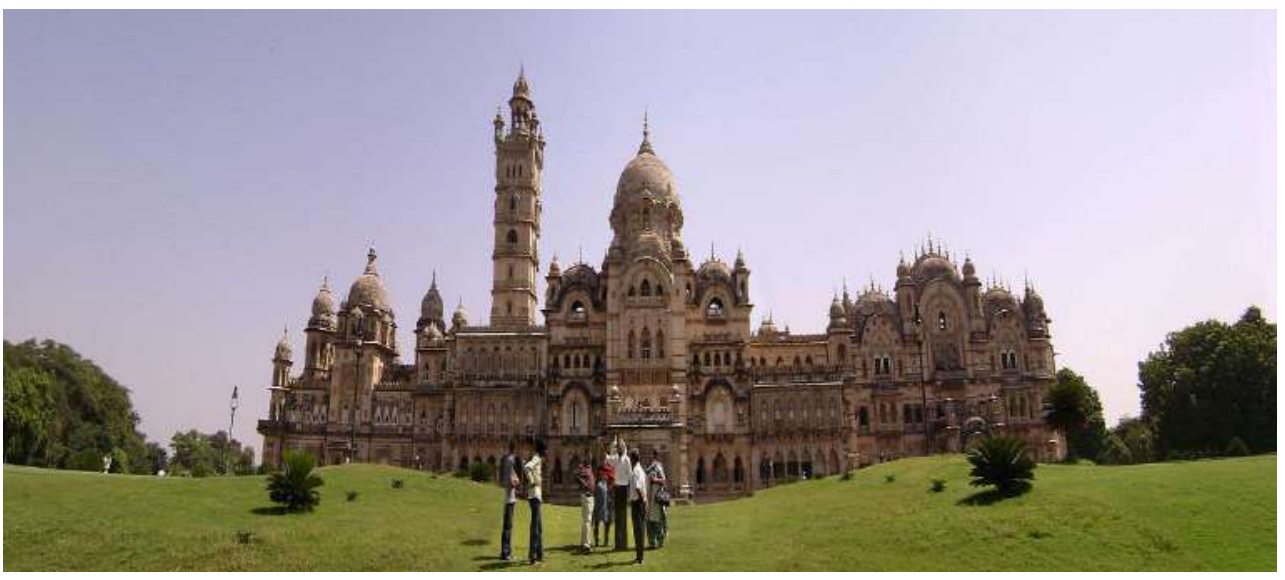

Lothal of Indus valley civilization (Ruins)

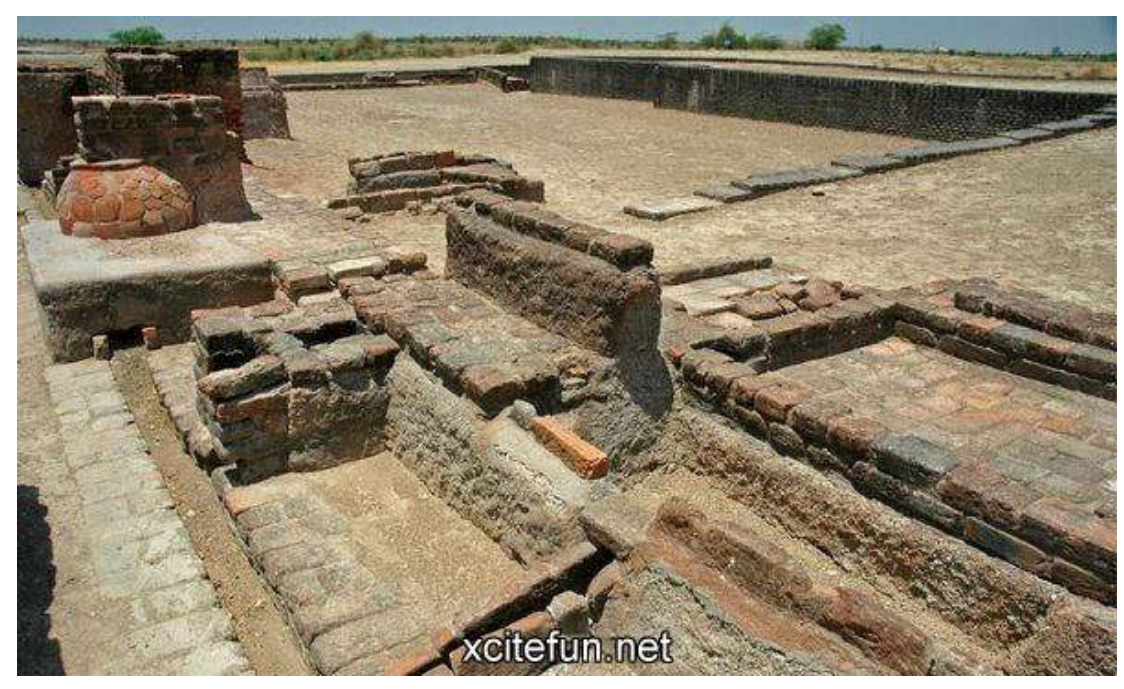


Towards Excellence: An Indexed, Refereed \& Peer Reviewed Journal of Higher Education / Dr. Priyanki

Vyas \& Ms. Daxa Patel / Page 386-398

\section{References}

"15 Historical Monuments of National Importance in Gujarat." WalkThroughIndia 15 Historical Monuments of National Importance in Gujarat Comments, www.walkthroughindia.com/attraction/15-historical-monuments-national-importancegujarat/.

“16 Best Places To Visit In Daman And Diu.” Treebo Blog, 6 Aug. 2018, www.treebo.com/blog/places-to-visit-in-daman-diu/.

Centre, UNESCO World Heritage. "Historic City of Ahmadabad." UNESCO World Heritage Centre, whc.unesco.org/en/list/1551/.

Editor|, Shikha GautamShikha Gautam|Times Travel. "Inside Gujarat's Marvellous Architectural Wonders." Times of India Travel, 25 Apr. 2019, timesofindia.indiatimes.com/travel/destinations/inside-gujarats-marvellous-architecturalwonders/as69038183.cms.

"Gujarat.” Encyclopcedia Britannica, Encyclopædia Britannica, Inc., www.britannica.com/place/Gujarat.

"List of Monuments of National Importance in Gujarat." Wikipedia, Wikimedia Foundation, 2 Jan. 2021, en.m.wikipedia.org/wiki/List_of_Monuments_of_National_Importance_in_Gujarat.

“Lothal.” Wikipedia, Wikimedia Foundation, 5 Jan. 2021, en.m.wikipedia.org/wiki/Lothal.

“Modern Architecture." Modern Architecture - A Complete Ahmedabad City Guide by Dr. Manek Patel, www.welcometoahmedabad.com/127/modernarchitecture.html\#: :text=Among\%20the \%20structures\%20that $\% 20$ came,Gajjar\%20(1900 $\% 2$ D 1960).\&text $=$ These $\% 20$ institutional $\% 20$ buildings $\% 20$ are $\% 20$ the $\% 20$ specimens $\% 20$ o $\mathrm{f} \% 20$ modern $\% 20$ architecture.

“Sabarmati Riverfront.” Wikipedia, Wikimedia Foundation, 6 Jan. 2021, en.m.wikipedia.org/wiki/Sabarmati_Riverfront.

"Salient Features of Architecture - Forts and Monuments." Gujrat PCS Exam Notes, 22 Mar. 2020, gujarat.pscnotes.com/art-and-culture/salient-features-of-architecture-forts-andmonuments- $2 /$.

shaaz_bazmi Follow. “Gujrat Provincial Architecture.” SlideShare, 14 Mar. 2018, www.slideshare.net/mobile/shaaz_bazmi/gujrat-provincial-architecture.

“Sidi Saiyyed Mosque.” Wikipedia, Wikimedia Foundation, 23 Dec. 2020, en.m.wikipedia.org/wiki/Sidi_Saiyyed_Mosque.

“Top 7 Architectural Wonders of Gujarat.” InGujarat.in, 11 Aug. 2018, ingujarat.in/culture/toparchitectural-wonders-of-gujarat/. 
Towards Excellence: An Indexed, Refereed \& Peer Reviewed Journal of Higher Education / Dr. Priyanki

Vyas \& Ms. Daxa Patel / Page 386-398

"What Is Modern: Characteristics of Modern Architecture." a2 Modern, www.a2modern.org/2011/04/characteristics-of-modern-architecture/.

“What to Learn from Gujarat Homes?” Happho, 4 June 2020, happho.com/learn-gujarat-homes/.

Wikipedia, Wikimedia Foundation, 8 Dec. 2020, en.m.wikipedia.org/wiki/Sun_Temple,_Modhera\#Architecture.

Dr. Priyanki Vyas

Head \& Associate Professor

Department of Library and Information Science

Dr. Babasaheb Ambedkar Open University (BAOU),Ahmedabad

Mobile Number : 9408778536, E-mail : priyanki.vyas@baou.edu.in

\&

Ms. Daxa G. Patel

Research Scholar

Department of Library and Information Science

Dr. Babasaheb Ambedkar Open University (BAOU), Ahmedabad

Mobile Number : 9924010826, E-mail : daxa2407@gmail.com 